\title{
16
}

\section{Attitudes towards using computers among Malaysian teacher education students}

\author{
Zoraini Wati Abas \\ University of Malaya \\ Kuala Lumpur \\ Malaysia
}

\begin{abstract}
The Malaysian government hopes to introduce computers in schools on a wider scale. Success will be determined by teachers' attitudes towards working with computers. A study was conducted to determine the computer attitudes among a group of teacher education students in Malaysia. The group consisted of 360 teacher education students at the Faculty of Education, University of Malaya. The Computer Attitude Scale (CAS) was used. The study also investigated relationships between selected independent variables (gender, frequency of computer use, length of computer use) and four types of computer attitudes (anxiety, confidence, liking and usefulness).
\end{abstract}

Main conference themes: developing countries, teacher education

Educational areas: higher education

Study topics:

Secondary keywords: attitudes, research 


\section{INTRODUCTION}

The computer has stirred wide and strong interest in education over the past decade. In many developed countries teachers are already using computers in the classrooms. Developing countries such as Malaysia are trying to introduce computers in schools on a national scale. This is necessary because information technology tools such as the computer have made a great impact in developed societies and will soon be widely used by many segments of society worldwide. Hence schools should be taking steps to produce a generation of proficient computer users for the workplace.

To help achieve this the Malaysian Ministry of Education has embarked on two national computer literacy projects in schools, has encouraged formation of school computer clubs, has almost completed development of an authoring system and will soon launch a telecommunications project to connect schools to the rest of the world via the Internet.

These efforts indicate how serious the Malaysian government takes incorporation of computer technology in schools. However, Malaysian teachers tend to shy away from computers. It is estimated that only about $5 \%$ of Malaysian teachers use computer. More Malaysian teachers need to be trained and prepared to use computers in schools, if the government's efforts to introduce computers in schools are to be successful. One way to train teachers would be to introduce a course on computer use in the classroom in pre-service teacher training programmes.

However, research has shown that one factor in the successful implementation of computers in educational institutions is user acceptance and user acceptance is believed to be influenced by user attitudes [1]. It is expected that once user attitudes are identified, steps may be taken to change these attitudes, if necessary. Teachers' attitudes have also been found to be the key to the successful implementation of computers in schools [2, 3]. Merely having computers in the school will not mean that these will be used to the best advantage [4]. It is also believed that teacher education students' attitudes toward working with computers indicates future computer use in instructional settings [4]. On these considerations the study reported in this paper was designed to measure Malaysian teacher education students' attitudes toward using computers.

Also in one computer attitude study [1] male students tend to show higher positive attitudes toward computers than female students [1]. In addition it had been found that previous computer use was one of the factors which was significantly related to more positive computer attitudes [1, 4]. Increasing amounts of computer experience were also associated with more positive attitudes toward computers $[1,5]$. Thus factors such as gender and amount of 
computer experience (frequency of computer use and length of computer use) were given attention in the Malaysian study.

\section{PURPOSE OF THE STUDY}

As mentioned the purpose of this study was to determine the attitudes toward using computers among Malaysian teacher education students. Four types of attitudes were defined: computer anxiety, computer confidence, computer liking and perceived usefulness of computers.

Computer anxiety is defined as fear of computers or anxiety towards using computers. Computer confidence is defined as an ability to learn about or use computers. Computer liking is defined as joy in using computers. Perceived computer usefulness is defined as the ability to perceive computers as a useful tool.

Responses to several questions were also used to determine the relationship between the selected variables of gender, frequency of computer use and length of computer use on the four computer attitudes (anxiety, confidence, liking and perceived usefulness).

\section{METHODOLOGY}

\section{Sample}

The sample for this study consisted of 360 students enrolled in the Diploma of Education programme at the Faculty of Education, University of Malaya in Kuala Lumpur, Malaysia. They would be posted as teachers in less than one year from the time the study was conducted.

The questionnaire was administered on the first day of the 1994/1995 academic session during one of the lectures. The sample comprised 65 (18.1\%) male students and $295(81.9 \%)$ female students. The age of the students ranged from 23 to 34 years old with the mean age being 24.75 years old. The majority, that is $82.5 \%$ of students, were between 23 and 25 years old.

\section{Instrumentation}

A questionnaire in Malay, the national language of Malaysia, was developed for the study. It comprised of two sections. One section was designed to collect the respondent's demographic data such as sex, age, frequency and length of computer experience. The other section consisted of 40 Computer Attitude 
Scale (CAS) items to measure the four types of attitudes. The CAS items have been used in a number of studies [1], [6], [7].

The original CAS items in English were translated into Malay and retranslated to ensure that the meaning was the same. Each type of attitude is measured by ten related statements such as: "computers do not scare me at all" or "I would feel at ease with a computer". Some of the questions were positively and some were negatively stated to avoid response set. The 40 items were intermixed.

Response to each item was based on a Likert scale ranging from 1 to 4 . For positively worded items $1=$ strongly disagree, $2=$ disagree, $3=$ agree and $4=$ strongly agree. The values were reversed for negatively worded items. For items in the computer anxiety subscale the numbers were recoded so that a score of 1 means low anxiety and a score of 4 means high anxiety.

In several studies CAS has been found to be reliable in measuring teachers' computer anxiety, computer confidence, computer liking and perceived usefulness of the computer [5], [7[, [8], [9], [10], [11]. For this study, the reliability coefficients for internal consistency were respectively $.85, .81, .81$ and .76 for anxiety, confidence, liking and usefulness. Total score reliability was .94. It is believed that the CAS, now in the Malay language, is a reliable instrument for determining Malaysian teachers' attitudes towards using computers. For comparison we give the internal consistency reliability of the four subscales in one particular study [7]: respectively $.90, .89, .89$ and .82 for anxiety, confidence, liking and usefulness. In another study the results of the coefficient alpha reliability for the computer anxiety, computer confidence, computer liking, perceived usefulness and total scores were: $.93, .91, .93, .86$ and .97 , respectively [1].

\section{Research Questions}

The main research question was: What is the overall attitude (computer anxiety, computer confidence, computer liking, and computer usefulness) of Malaysian teacher education students toward computer use?

In addition the study was designed to answer the question: Are there statistically significant relationships between selected independent variables (gender, frequency of computer use, length of computer use) and the four types of attitudes (computer anxiety, computer confidence, computer liking and computer usefulness)? 


\section{FINDINGS}

In response to questions relating to their previous computer experience, it was found that 330 or $91.7 \%$ of the students have had some kind of computer experience. Only 26 students $(7.3 \%)$ have never used the computer prior to filling out of the questionnaire. Four failed to respond and were treated as missing cases.

Among the respondents who have used computers, wordprocessing was the most predominant type of experience. More than one third of the computer using group, that is 129 students or $39.09 \%$, have used it a lot; that is, more than 20 times in the past. This is followed by use of spreadsheets (33 students or $10 \%$ ), graphics (24 students or $7.3 \%$ ) and programming (24 students or $7.3 \%)$. Only 17 students (5.2\%) have used database management systems in a considerable way. In short, the most common software used was the wordprocessor followed by spreadsheets, graphics, programming and database management.

It is interesting to note that, when it comes to use of the latest technology, $62(7.2 \%)$ of the students have used CD-ROM for research, knowledge finding and recreation. Eighty-five (23.6\%) students in the group have heard of electronic mail (e-mail), but only 32 students $(8.9 \%)$ have used e-mail facilities prior to the study.

A majority of 321 students (89.2\%) expressed interest in taking a computer course as part of their teacher training program. When asked if they would use a computer when they teach in school, 350 students (97.2\%) said yes.

Table 1 Mean subscale scores on the CAS $(\mathrm{N}=360)$

\begin{tabular}{lllll}
\hline $\begin{array}{l}\text { Attitude } \\
\text { Subscale }\end{array}$ & $\begin{array}{l}\text { Mean } \\
\text { Score }\end{array}$ & $\begin{array}{l}\text { Standard } \\
\text { Deviation }\end{array}$ & $\begin{array}{l}\text { Minimum } \\
\text { Score }\end{array}$ & $\begin{array}{l}\text { Maximum } \\
\text { Score }\end{array}$ \\
\hline Anxiety & 21.48 & 3.25 & 13 & 35 \\
Confidence & 28.53 & 3.60 & 17 & 40 \\
Liking & 29.81 & 3.59 & 18 & 40 \\
Usefulness & 32.48 & 3.40 & 21 & 40 \\
\hline
\end{tabular}

Table 1 shows the mean scores of each attitude subscale (computer anxiety, confidence, liking, and usefulness). The neutral score is 25 . The minimum score is 10 for each of the subscales. The maximum possible total score for each subscale is 40 , based on a maximum score of 4 for each of the ten items. The means indicate that the group of students has a somewhat low anxiety, 
somewhat high confidence, tend to like computers and have a positive perception of the computer's usefulness.

A computer attitude study conducted earlier among 518 California State University (CSU) teacher education students found that the scores for computer anxiety, confidence, liking and usefulness were 18.49, 31.70, 30.91 and 35.16, respectively. It can be concluded that teacher trainees at CSU tend to have lower anxieties and more confidence in using the computer, more liking for the computer and perceived the computer to be more useful than their Malaysian counterparts [4]. This may be due to the fact that computers have made a greater impact in advanced societies such as that of the United States of America. In such developed countries there are more computers being used and these are used by a higher percentage of society.

\section{Gender}

As Table 2 shows, this study found that males have lower computer anxiety than females, more confidence in using computers compared to females. They like to use the computer to about the same degree as females and find the computer more useful. A t-test was performed to examine if there were any statistically significant relationships between gender and each of the four types of attitudes (Table 2). It was only significant on the confidence subscale ( $p<$ 0.01 ). The mean confidence subscale score for males was 29.64 , while the females scored 28.29.

Table 2 Mean subscale scores according to gender $(\mathrm{N}=360)$

\begin{tabular}{llllll}
\hline Gender & $N(\%)$ & Anxiety & Confidence & Liking & Usefulness \\
\hline Male & $65(18.1)$ & 20.87 & 29.64 & 29.80 & 32.71 \\
Female & $295(81.9)$ & 21.61 & 28.30 & 29.81 & 32.44 \\
& & $\mathrm{t}=1.63$ & $\mathrm{t}=2.68^{* *}$ & $\mathrm{t}=0.03$ & $\mathrm{t}=0.58$ \\
\hline
\end{tabular}

$* * \mathrm{p}<0.01$

\section{Frequency of computer use}

Respondents were asked to indicate their frequency of computer use (none, once or twice, sometimes, always) prior to the study. Only 330 respondents have used computers before the study was conducted. The results are shown in Table 3. The table shows that the more frequent the computer use, the less anxiety a person feels towards using the computer. The more confident a person feels in using the computer, the more the person likes the computer and the more useful the computer is perceived to be. 
Results of the ANOVA procedure revealed that there were statistically significant relationships at $p<0.001$ between frequency of computer use and three of the attitude subscales (computer anxiety, computer confidence and computer liking). The relationship between frequency of computer use and perceived usefulness of the computer was statistically significant at $p<0.01$.

\section{Length of computer use}

There were 319 responses in all. Forty-one respondents did not answer, out of which, 26 have never used computers. It was found that there is a relationship between how long a person has used computers and his or her attitude toward using computers. Generally, the longer the experience, the less anxious one gets. Results of the study are shown in Table 4. The relationships as revealed by the ANOVA procedure were found to be statistically significant between length of computer use and computer anxiety as well as computer confidence at $p<0.001$; and between length of computer use and computer liking $(p<0.05)$. There was no statistically significant relationship between length of computer use and perceived computer usefulness $(\mathrm{p}<0.05)$.

Table 3 Mean subscale scores according to frequency of computer use $(\mathrm{N}=356)$

\begin{tabular}{llllll}
\hline Frequency & $\mathrm{N}(\%)$ & Anxiety & Confidence & Liking & Usefulness \\
\hline None & $26(7.3)$ & 23.45 & 25.60 & 27.88 & 30.68 \\
Once or twice & $70(19.7)$ & 23.17 & 27.19 & 29.28 & 32.09 \\
Sometimes & $205(57.6)$ & 21.22 & 28.65 & 29.81 & 32.57 \\
Always & $55(15.4)$ & 19.54 & 31.07 & 31.35 & 33.46 \\
\hline & & F Ratio $=$ & F Ratio $=$ & F Ratio $=$ & F Ratio= \\
& & 17.607 & 20.620 & 6.397 & 4.215 \\
& & F Prob $=$ & F Prob $=$ & F Prob $=$ & F Prob= \\
& & $0.000 * *$ & $0.000 * *$ & $0.0003 * *$ & $0.006 * *$ \\
** $<<0.01$ & & & & \\
\hline
\end{tabular}

\section{DISCUSSION AND IMPLICATIONS OF THE STUDY}

The study has found that students in a teacher education programme in one of the higher educational institutions in Malaysia have positive attitudes toward computers. The study indicates that the students have a somewhat low computer anxiety, are fairly confident in using computers, like to use computers and perceive the computer to be useful. This is consistent with their 
responses to questions: (a) if they were interested in taking a computer course during their Diploma of Education programme and (b) if they would use the computer in school.

Table 4 Mean subscale scores according to length of computer use $(N=319)$

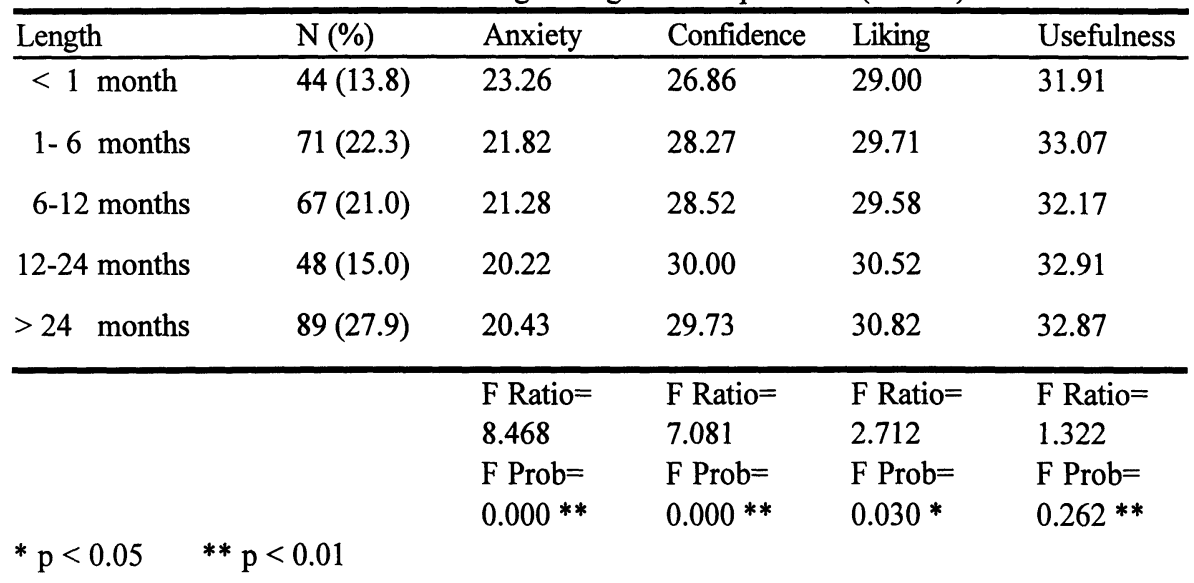

Prior to the study the respondents' main use of the computers was for wordprocessing. This may explain the overall positive attitudes found in the study. It supports various other studies where computer experience is linked to positive computer attitudes $[1,4]$.

The study also found that males tend to be more confident than the females in using computers. This can be explained in part by the fact that the computer field is dominated by males. Furthermore, the mass media usually portray males with computers on their desks.

This study also indicates that increased and frequent use of the computer will result in a person having lower anxiety in using the computer, more confidence in using the computer, more liking for the computer and will perceive the computer to be more useful. There were statistically significant relationships between frequency of computer use and the four types of computer attitudes.

In addition, there was a statistically significant relationship between length of computer use and computer anxiety, computer confidence and computer liking. Hence, one way to encourage more positive attitudes is for schools to provide facilities and encouragement to use the computer more often and to do more tasks on the computer.

These findings will be useful to the Malaysian government. It implies that Malaysian teacher education students have the right attitude to do well in a 
computer course, if it were included in their teacher training programme. Also they have accepted the use of computers in schools. In addition they are willing, ready and interested to use computers in schools.

Some of the new teachers who have the interest, can also be trained to develop Computer Aided Learning (CAL) courseware for the local schools with the soon-to-be released authoring system. Furthermore some of the new teachers can help in the pilot project involving telecommunication activities.

While many Malaysian schools have bought or been supplied with computers for use by the students, almost none are available specifically for the teachers to use. In view of the findings of this study each school should place a microcomputer in the teachers' staff room, in the science laboratories and have at least one classroom designed for teachers who wish to integrate the use of the computer into noncomputer subjects. By doing so a computer using culture will result within the school in parallel with the objectives of the ministry in encouraging computer use among school children. Furthermore, it is likely that teachers' attitudes toward computers will be more positive.

Although the study was conducted in one institution, it is assumed that other groups of students undergoing teacher training in Malaysia may have similar attitudes in view of the similarity of their computer and curricular experiences. The study should however be replicated using samples from other groups of Diploma of Education students. It is also not known how willing and ready older and experienced teachers in Malaysia are to use computers. A study should next be conducted to determine the attitudes of this group, particularly, among teachers who have been teaching for ten years or more.

\section{REFERENCES}

1. Koohang, A.A. (1989) A study of attitudes toward computers: Anxiety, confidence, liking and perception of usefulness. Journal of Research on Computing in Education, 22 (2) pp. 137-50.

2. Hunter, W. and deLeeuw, G. (1988, June). Computers in teacher education. Paper presented to the Association for Media and Technology, Halifax.

3. Stevens, D.J. (1980) How educators perceive computers in the classroom. AEDS Journal, 13, pp. 221-32. 
4. Hunt, N. P. and Bohlin, R. M. (1993) Teacher education students attitudes toward using computers. Journal of Research on Computing in Education, 25 (4) pp. 487-497.

5. Gressard, C. P. and Loyd, B. H. (1985) Validation studies of a new computer attitude scale. Paper presented at the Annual Meeting of the American Educational Research Association, Chicago.

6. Loyd, B. H. and Gressard, C. P. (1985) The Computer Attitude Scale. (Survey instrument). Charlottesville, VA: University of Virginia, Curry School of Education.

7. Berberoglu, G. and Gage, C. (1993) Factorial validity of the Turkish Computer Attitude Scale. Studies in Educational Evaluation, 19 (3) pp. 257-63.

8. Loyd, B. H. and Loyd, D. E. (1985) The reliability and validity of an instrument for the assessment of computer attitudes. Educational and Psychological Measurement, 45 (4) pp. 903-908.

9. Kluever, R. C., Lam, T. C. M., Hoffman, E., Green, K. E. and Swearingen, D. L. (1992) The Computer Attitude Scale: Assessing teachers' attitudes toward computers. Paper presented at the annual meeting of the American Educational Research Association, San Francisco.

10. Woodrow, J. E. J. (1991) A comparision of four computer attitude scales. Journal of Educational Computing Research, 7 (2) pp. 165-67.

11. Gressard, C. P. and Loyd, B. H. (1985) Investigation of multiple matrix sampling for attitude data analysis. Paper presented at the Annual Meeting of the National Council on Measurement in Education, Chicago. 